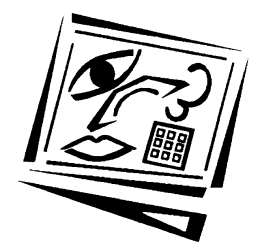

\title{
Developing technological pedagogical content knowledge in pre-service mathematics teachers through collaborative design
}

\author{
Douglas D. Agyei \\ University of Cape Coast, Ghana \\ Joke Voogt \\ University of Twente
}

\begin{abstract}
Although many studies have shown the need to pay attention to teachers' preparation for the integration of technology in classroom practice, most teachers in Ghana have not had any preparation that develops their technological pedagogical content knowledge (TPCK).This paper presents a case study of four pre-service mathematics teachers from the University of Cape Coast, Ghana, who worked in two design teams to develop lessons, and subsequently taught in a technology-based environment for the first time. It was evident from the findings that more systematic efforts are needed to engage pre-service teachers in technology-rich design activities, to develop their TPCK adequately. The study also showed the potential of TPCK as a new frame for developing pre-service teachers' experiences in technology integration within initial teacher education, particularly in Sub-Saharan African countries.
\end{abstract}

\section{Introduction}

Integration of technology in education has increasingly become an important concern in education not only in developed countries, but in developing countries as well. Tilya (2008) analysed the development of technology in education policies in SubSaharan Africa. He reported that the majority of Sub-Saharan Africa countries have a national policy on technology in education, including an implementation plan. Ghana is one of the Sub-Saharan African countries with a national policy and implementation plan for technology in education. Ghana introduced ICT into the school curriculum in September 2007 following the recommendations of the Ghana Information and Communication Technology for Accelerated Development (Ghana ICT4AD Policy, 2003) policy document and the Anamuah-Mensah National Education Review Committee Report (2002). Both documents highlight the importance of integrating ICT into the curriculum at all levels. The new curriculum in mathematics at the Senior High School (SHS) level encourages teachers to make use of the calculator and the computer to help students acquire the habit of analytical thinking and the capacity to apply knowledge in solving practical problems (Ministry of Education, Science and Sports (MOESS), 2007). However, to realise this new orientation to teaching and learning including the use of computers by teachers, more needs to be done than the current recommendations contained in syllabuses. 
Few studies conducted in Ghana report the poor state of mathematics and technology use in secondary education in Ghana. Agyei \& Voogt $(2011 \mathrm{a}, \mathrm{b})$ showed that mathematics teachers did not integrate technology in their instruction in spite of government efforts in the procurement of computers and recent establishment of computer labs in most senior high schools. Major barriers to technology integration were the current teaching strategies used in senior high schools, and lack of teachers' and pre-service teachers' knowledge of ways to integrate technology in instruction. The most frequently used strategy in the senior high school classrooms was the chalk and talk approach in which teachers did most of the talking and intellectual work, while students were passive receptacles of the information provided (Ottevanger, van den Akker \& de Feiter, 2007; Agyei \& Voogt, 2011a). Agyei and Voogt (2011a) reported that for most teachers, effectively integrating technology in their instruction was a complex innovation which required them to change their routines of teaching (cf. Koehler \& Mishra, 2008; Voogt, 2008). Agyei and Voogt (2011a, b) further indicated that most instructors at the teacher education program were mainly dependent on lecture-based instruction. Teacher education did not include instructional technology courses to prepare prospective teachers to integrate technology in their lessons. This means that the pre-service teachers' experience in integrating technology in teaching is limited, making the program fall short of a practical approach. This leads to the question whether the trained pre-service teachers are sufficiently prepared for new teaching methods which are flexible, student-centred and involve appropriate use of technology.

The study on Developing Science Mathematics and ICT (SMICT) education in Ghana suggested changes to the teacher's instructional role, from presenter of knowledge using drill-oriented methods, to participatory teaching and learning (Ottevanger, et al., 2007). More particularly, it recommended effective use of equipment for practical work and ICT, which needs to be optimised through extensive programs of pre-service and in-service teacher support. Agyei and Voogt (2011a, b) also found that mathematics teachers and pre-service mathematics teachers appeared generally supportive in wanting to use computers in their (future) classrooms, in spite of the barriers to technology use in instruction. These teachers showed enthusiasm to be part of any professional development program related to integrating technology in teaching and learning mathematics. In this study a professional development arrangement, in which pre-service mathematics teachers collaboratively design and use technology rich teaching materials, is carried out and evaluated, as a first effort to develop a technology integration program for pre-service mathematics teachers at the University of Cape Coast (UCC), Ghana. The study builds on the findings of a previous study (Agyei \& Voogt, 2011a, 2011b) and is part of an on-going program aimed at developing and integrating technology-rich design activities into the pre-service mathematics teacher education curriculum at UCC.

\section{Technology integration through collaborative design}

According to Koehler and Mishra (2008), at the heart of good teaching with technology are three core components: technology, pedagogy and content plus the relationships between them. Technological Pedagogical Content Knowledge (TPCK) was introduced to the educational research field as a theoretical framework for understanding teacher knowledge required for technology integration. TPCK builds on Schulman's concept of pedagogical content knowledge (Schulman 1986) which highlighted the importance of the complex inter-relationships between teachers' knowledge about content and 
pedagogy, and the need for teachers to learn about variable ways of representing subject matter. TPCK emphasises the comprehensive set of competencies teachers need to successfully integrate technology in their educational practices (Koehler \& Mishra, 2008). The key to TPCK is the integration of multiple domains of knowledge in a way that support teachers in teaching their students the subject matter with technology (Margerum-Leys \& Marx 2004; Niess 2005). TPCK consists of 7 different knowledge areas: (i) Content knowledge (CK), (ii) Pedagogical knowledge (PK), (iii) Technology knowledge (TK), (iv) Pedagogical content knowledge (PCK), (v) Technological content knowledge (TCK), (vi) Technological pedagogical knowledge (TPK), and (vii) Technological pedagogical content knowledge (TPCK) (see Figure 1).

Technology knowledge (TK) broadly encompasses knowledge of standard technologies such as books and chalk and blackboard, as well as more advanced technologies such as the Internet and digital video, and the different modalities they provide for representing information (Polly, Mims, Shepherd \& Inan, 2010). Technological content knowledge (TCK) refers to knowledge about how technology may be used to provide new ways of teaching content (Niess, 2005). Technological pedagogical knowledge (TPK) refers to knowledge about the affordances and constraints of technology as an enabler of different teaching approaches (Koehler \& Mishra, 2008).

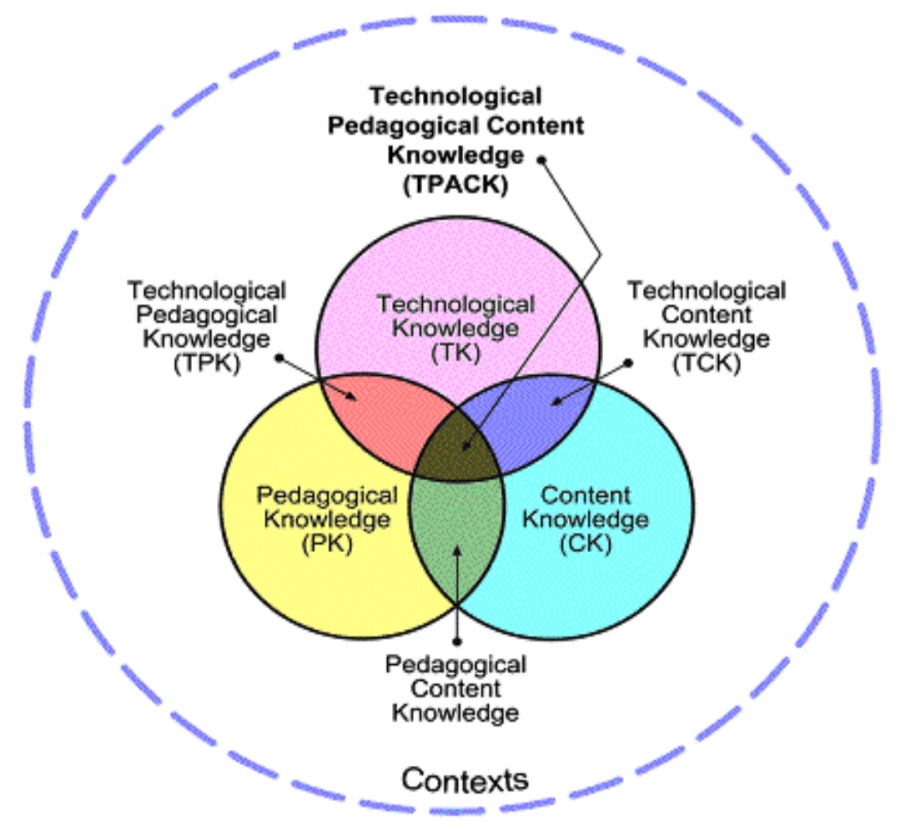

Figure 1: Framework of TPCK: (Koehler \& Mishra, 2008).

Technological pedagogical content knowledge (TPCK) also refers to the knowledge and understanding of the interplay between CK, PK and TK when using technology for teaching and learning. Considering the goal of engaging students in mathematical problem solving for example, a mathematics teacher's TPCK must focus on thinking strategically in planning, organising, implementing, critiquing results and abstracting plans for specific mathematics content and diverse student needs (Niess, Sadri \& Lee, 2007). Since this study describes and evaluates a professional development 
arrangement for pre-service mathematics teachers' development of TPCK, we focus particularly on the knowledge areas in which the ' $\mathrm{T}$ ' is involved: TK, TCK, TPK and TPCK, and engage the teachers in a collaborative way to design technology-rich activities.

Several studies (Koehler \& Mishra, 2005; Koehler, Mishra \& Yahya, 2007; Polly et al., 2010; So \& Kim, 2009) have shown that collaborative design of technology enhanced curriculum materials support teachers in becoming TPCK competent. Koehler et al. (2007) indicated that a key to learning about TPCK is the "Learning Technology by Design" approach, in which pre-service teachers participate in "design teams" that serve "as a collaborative learning context in which a pre-service teacher is engaged to become "a practitioner, not just learning about practice" (p.135). Similarly, Angeli and Valanides (2005) argued that such a design-based learning approach contributes to preparing future teachers to be competent to teach with technology in ways that signify the added value of technology. So and Kim (2009) indicated that collaborative designs help pre-service teachers to make intimate connections among content, pedagogy and technology in a collaborative way. According to Mishra, Koehler and Zhao (2007), learning technology through collaborative design seeks to put pre-service teachers on a common ground as they work collaboratively in small groups to develop technological solutions to authentic pedagogical problems.

In this study, the concept of Design Teams (DTs), defined as a group of pre-service teachers working collaboratively to design and develop technological solutions for authentic problems they face in teaching mathematics during their in-school training, was applied to actively involve pre-service teachers in the design of curriculum materials to develop their TPCK. It is expected that by working in DTs to design technological solutions, pre-service teachers will begin to think about technology as a tool for achieving instructional objectives, rather than considering it as an end in itself. Again we expect that engaging pre-service teachers in DTs, will promote active learning, through collaboration with the different team members.

Because exemplary curriculum materials should speak to the teacher instead of through the teacher (Remillard, 2005), much emphasis was placed on exemplary curriculum materials that were designed specifically to help pre-service teachers learn through design and implementation of the innovation in the study. Several researchers have investigated the contributions of curriculum materials designed to support teacher learning (Van den Akker, 1988; Davis \& Krajcik, 2005; Remillard, 2000), referred to by Davis and Krajcik as "educative curriculum materials". Such studies have shown that exemplary curriculum materials provide teachers with an operational understanding of an innovation (van den Akker, 1988), stimulate reflection (Davis \& Krajcik, 2005) and subject matter understanding (Ottevanger, 2001). According to Voogt (2010), exemplary materials can provide pre-service teachers with theoretical and practical insights into technology-supported learner-centred lessons and hands on experience, and the use of exemplary materials in this study had a focus in this direction.

\section{The specific application of TPCK in this study}

In the research, pre-service teachers' knowledge which is needed to teach spreadsheetsupported lessons in mathematics was operationalised as their TPCK. As shown in Figure 2, the technology learned by the pre-service teachers (further addressed as 
experimental teachers) was spreadsheet applications for mathematics, because it has potential for supporting students' higher-order thinking in mathematics. It is user friendly (Niess, Sadri \& Lee, 2007), and readily available in senior high schools and in teacher education colleges (Agyei \& Voogt, 2011a). The content knowledge was mathematics which was the pre-service teachers' teaching subject area and the pedagogical approach was not specified. Pre-service teachers were asked to carefully choose instructional strategies they felt would be useful in supporting their lessons.

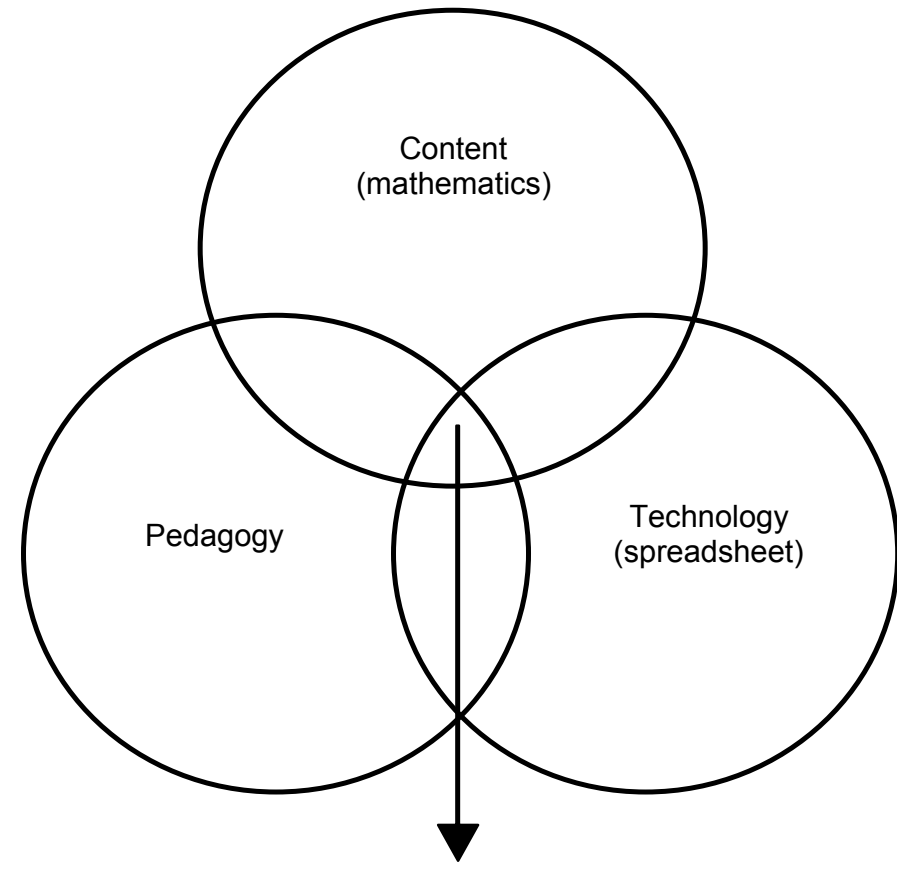

Technological pedagogical content knowledge for spreadsheet-supported lesson in mathematics (TPCK)

Figure 2: Framework of TPCK used in the study

The TPCK components as defined for this study consisted of the following specific knowledge:

- Technological knowledge (TK): knowledge about use of spreadsheets; its affordances and constraints.

- Technological content knowledge (TCK): the knowledge of representing mathematical concepts in a spreadsheet.

- Technological pedagogical knowledge (TPK): The knowledge of how to use spreadsheets in teaching.

- Technological pedagogical content knowledge (TPCK): the knowledge of representing mathematical concepts with spreadsheet. 


\section{The professional development arrangement}

The professional development arrangement in this study consisted of three stages: An introductory workshop for DTs, design of lessons in DTs and implementation of lessons by DT members. The workshop lasted for two weeks and was meant to update pre-service teachers on theoretical foundation/concepts (e.g. TPCK framework, collaborative teacher design and pedagogical strategies) as well as practical skills they needed to work successfully during the other stages (design and implementation) of the study. During this period, two spreadsheet-supported lesson (SSL) models (designed by the researcher) were taught by the researcher as demonstration lessons and discussed with the teams. The arrangement also gave DTs the opportunity to code TPCK components in the exemplary lesson materials (as well as evaluating them) and also work on assignments to design activities with spreadsheets in specified topics. Sessions of the professional development included interactive discussions on readings and class assignment. Micro-teaching in which teams taught their peers during teaching try-outs was a necessary activity. Table 1 presents an overview of the DT activities in relation to the TPCK framework.

Table 1: Relation between DT activities, TPCK framework and strategies for teacher learning

\begin{tabular}{|l|c|c|}
\hline \multicolumn{1}{|c|}{ DT activities } & Stage & $\begin{array}{c}\text { TPCK } \\
\text { framework }\end{array}$ \\
\hline Introduction to learning by design (collaboration) & $\mathrm{w}$ & - \\
\hline Introduction to computer skills (including spreadsheet basics) & $\mathrm{w}$ & $\mathrm{TK}$ \\
\hline Introduction to TPCK concept & $\mathrm{w}$ & TPCK \\
\hline $\begin{array}{l}\text { Introduction/demonstration of spreadsheet-based lesson (exemplary } \\
\text { material) and discussion }\end{array}$ & $\mathrm{w}$ & TPCK \\
\hline Scouting spreadsheet techniques that support mathematics teaching & $\mathrm{w} / \mathrm{d}$ & $\mathrm{TPK}$ \\
\hline $\begin{array}{l}\text { Development of mathematics SSL activities by teachers } \\
\text { Teaching of SSL to colleagues/ peers/ researcher } \\
\text { (use of teachers' developed lesson materials) }\end{array}$ & $\mathrm{d} / \mathrm{i}$ & $\mathrm{TCK}$ \\
\hline Revision of the developed lesson materials based on feedback & $\mathrm{w} / \mathrm{d} / \mathrm{i}$ & TPCK \\
\hline
\end{tabular}

Based on their experiences, the DTs developed and modelled their own lessons (lesson plans and students' worksheet) after the exemplary materials during the design stage (which lasted for 3 weeks). These, they taught first as a micro-teaching exercise among themselves and later among their peers (further addressed as student-teachers) in a designed classroom situation during implementation. Each member of the DT taught one out of the four lessons (which lasted for 80 minutes each) although they had worked in teams to design them. The student teachers (who served as students in the classrooms) appraised the lessons. The lessons were done in a classroom with a LCD projector and a laptop computer available to each teacher. The results and insights learned from the teaching try-outs (micro-teaching and classroom implementation) served as necessary inputs for the teachers in revising their designs. The researcher acted mainly as a facilitator, coach and observer in different stages of the study.

\section{Research questions and research design}

The study examined the impact of collaborative design of technology-enhanced lesson materials in design teams on experimental teachers' classroom practices, and their learning of TPCK. The main research question that guided the study was: What are 
pre-service mathematics teachers' experiences in developing and implementing technology-enhanced lessons through collaborative design teams? The following sub research questions guided the study (1) how did the experimental teachers implement the developed technology-enhanced lesson materials in their teaching; (2) how did student-teachers experience the technology-enhanced lessons; (3) how did experimental teachers' learning of TPCK develop; and (4) how did the experimental teachers perceive the contribution of DTs and exemplary lesson materials to their learning?

A case study of 4 pre-service teachers was applied (Yin, 1993). The study focused on an in-depth investigation of the pre-service teachers' development of TPCK as well as their perceptions on how DTs contributed to their TPCK development. Consequently, the units of analysis were the pre-service teachers and the case was the professional development arrangement which was organised within the context of the mathematics teacher education program at the University of Cape Coast. The study employed mixed method of quantitative and qualitative evidence.

\section{Methods}

\section{Participants}

Four pre-service mathematics teachers (experimental teachers) and their student peers $(\mathrm{N}=125)$ (student-teachers) participated in the study. Both groups of participants were in their final year of the teacher education (BEd Mathematics) program at UCC. The BEd (Mathematics) is a 4-year program which will qualify them to teach at Junior and Senior High School when they graduate. In the study the experimental teachers: Isaac, Nat, Kobby and Serena (pseudonyms) worked in teams (Nat and Isaac; Kobby and Serena) to develop and teach SSL (to the student-teachers).These experimental teachers had no previous experience in a technology-supported lesson, either as part of their training or in their pre-university education at the senior high schools, and were all deep-rooted in teacher-centred approaches. The 4 teachers were selected on purpose to allow for in-depth investigations on a small scale; the study was a first effort to develop a technology integration program for pre-service mathematics teachers in Ghana. The student-teachers, who volunteered to be part of the study, were 90 males and 35 females. Just like the experimental teachers, the student teachers had no experiences with technology-supported lessons. The participants were aged between 19 and 37 with the average age of nearly 26 years.

\section{Instruments}

\section{Experimental teacher interview}

Interview data was collected after each peer teaching session. This interview focused on teachers' experiences and opinions of the SSL; reflecting their views from the planning and preparation stage to the actual implementation of lessons as well as a post- review of the teaching. Interview data was also taken at the end of the arrangement to seek the teachers' opinion on aspects of the program impacting on their professional development. All interviews were audio recorded and transcribed using pattern coding techniques (Miles \& Huberman, 1994).

\section{Experimental teacher evaluation questionnaire}

Since the study aimed at enhancing teachers' technological pedagogical content knowledge (TPCK), the questionnaire included items that addressed the experimental 
teachers' self-assessment toward TPCK, adapted from Schmidt, Baran, Thompson, Mishra, Koehler \& Shin (2009). Construct validity analysis of the items of the framework ranged from 3.67 to 9.00 of the knowledge types with five of the seven types scoring 7.88 (Schmidt, Seymour, Baran \& Thompson, 2009). Cronbach's alpha reliability estimates for this instrument ranged from 0.75 to 0.93 (Schmidt et al., 2009) suggesting that the instrument is reliable and could be used with confidence. Items were adapted to address the integration of spreadsheets in mathematics teaching in particular. The focus was teachers' knowledge related to technology integration: TK, TPK, TCK and TPCK (see also Table 2).

Table 2: Sample question for each TPCK knowledge type constructs

\begin{tabular}{|l|l|}
\hline \multicolumn{1}{|c|}{ Knowledge type } & \multicolumn{1}{c|}{ Sample question for each knowledge type } \\
\hline Technology knowledge (TK) & I frequently play around with spreadsheets \\
\hline $\begin{array}{l}\text { Technology pedagogical } \\
\text { knowledge (TPK) }\end{array}$ & $\begin{array}{l}\text { I can choose spreadsheets application that enhance the } \\
\text { teaching approaches of a lesson }\end{array}$ \\
\hline $\begin{array}{l}\text { Technology content knowledge } \\
\text { (TCK) }\end{array}$ & $\begin{array}{l}\text { I know about spreadsheet applications that I can use for } \\
\text { understanding and doing mathematics }\end{array}$ \\
\hline $\begin{array}{l}\text { Technology, pedagogy and content } \\
\text { knowledge (TPCK) }\end{array}$ & $\begin{array}{l}\text { I can teach lessons that appropriately combine mathematics } \\
\text { concepts, spreadsheet applications and teaching approaches }\end{array}$ \\
\hline
\end{tabular}

The questionnaire contained items on a five-point Likert scale $(1=$ strongly disagree, 5 = strongly agree) about teachers' self-efficacy toward technology use. Bandura (1977) presented self-efficacy as one's perceived ability to perform an action that will lead successfully toward a specific goal. The questionnaire was administered twice: before and after the intervention. Teachers' responses in the pre-post survey expressed teachers' disposition toward ongoing evolving of understanding and mastery of spreadsheets (TK), possibilities for teaching and learning with spreadsheets (TPK), how to use spreadsheets to increase understanding of mathematics concepts (TCK), and their understanding of how teaching and learning mathematics changed with the application of spreadsheets (TPCK).

Student-teachers' experiences with the spreadsheet-supported lessons (SSL)

A questionnaire consisting of 23 items on student-teachers' opinions of the SSL was administered immediately after each lesson implementation. Possible answers to an item were on a five point Likert scale $(1=$ strongly disagree, $5=$ strongly agree). Seventeen of the items were selected as high loadings on extracted factors after an exploratory factor analysis. In all, 3 sub-scales were reported. They were: Interest (how appealing/ motivating/ exciting and attention-grabbing a lesson was); Clarity (students' comprehension/understanding of the concepts of the lesson); and Presentation (the practice of showing and explaining content of the topic to the learners using technology). The reliability co-efficient observed for the scales were Interest $(a l p h a=0.74)$, Clarity $(a l p h a=0.71)$ and Presentation $(a l p h a=0.70)$. Following the administration of the questionnaire, a guided group discussion with 6 to 9 studentteachers was conducted to seek further clarifications of their opinions about the SSL in general and their learning and usefulness of the exemplary materials. The discussions were audio-recorded and transcribed using data reduction techniques (Miles \& Huberman, 1994).

Researcher's logbook

The researchers' log book was used to maintain a record of activities and events occurring during the classroom implementation of the SSLs as well as contributions of components of the arrangement in enhancing experimental teachers' TPCK. 
Information recorded in the logbook was analysed qualitatively using data reduction techniques (Miles \& Huberman, 1994).

\section{Results}

\section{Experimental teachers' practice}

Spreadsheet-supported lesson implementation

The first research question dealt with how the experimental teachers implemented the technology-enhanced lesson materials in teaching. A major aspect of the professional development arrangement was the SSL designed by the experimental teachers. By changing parameters in cells $(T K)$, the experimental teachers used a spreadsheet in an "interactive demonstrative" lecture, stimulating students' discussions with worksheets $(T P K)$ to help students explore mathematics concepts and perform authentic tasks (TPCK). Activities were carried out in groups (2-3 student-teachers) on the worksheets and this promoted healthy interactions among students, and also between students and the teacher. For instance, Kobby taught a topic on linear functions and like Isaac (who taught a lesson on quadratic functions) he used a spreadsheet to guide his students to explore patterns (see how changes in parameters affect graphs) to assist them in making generalisations from the observed patterns (TPCK). Visual representations of algebraic functions provided immediate feedback (TCK), which allowed learners to concentrate more on mathematical relationships rather than on the mechanics of construction (TCK). Furthermore, graphic representations from the use of the spreadsheet made it relatively easy for the teachers to guide their students in identifying properties of families of functions such as linear functions (as in Kobby's lesson) and quadratic functions (as in Isaac's lesson).

All teachers introduced fundamental concepts of their lessons by using spreadsheets and gradually engaged their students to develop higher concepts as lessons progressed. The teachers were able to demonstrate a wide range of examples of graphs by changing variables in cells (on the spreadsheet) without having to draw them physically $(T C K)$. As a result learners were able to explore many graphs in a shorter time, giving them greater opportunity to consider general rules and test and reformulate hypotheses. Student-teachers confirmed having discovered new things during the lessons. For instance during Serena's lesson (quadratic in the vertex form), most student-teachers identified that the basic second-degree curve $\left(y=a x^{2}\right)$ gives a thinner parabola if $|a|$ is increased and a flatter parabola if $|a|$ is decreased (which they did not know before the lesson). Time management was a setback for the experimental teachers during their lesson enactment. They all found some difficulty in completing lessons within the stipulated time. In most cases, the introduction of the lesson took more time. In spite of this limitation, results of the classroom observations reflect a positive impact of the in-service arrangement on the experimental teachers' classroom practices with SSL, taking into account that these teachers had never been exposed to technology use in classroom prior to the arrangement.

Student-teachers' experiences with the SSL lessons

The results of the study showed that student-teachers were satisfied with various aspects of the lesson as reported in their questionnaire responses (see Table 3). The overall means of aspects of the lesson reported by the students were very high; Clarity $($ Mean $=4.45, \mathrm{SD}=0.35)$, Interest $($ Mean $=4.43, \mathrm{SD}=0.37)$ and Presentation $($ Mean $=$ $4.35, \mathrm{SD}=0.36)$. A one-way ANOVA test was conducted to evaluate to what extent 
differences between their perceptions for the four lessons were significant across the three subscales. The ANOVA was significant $(F(3,121)=4.77, p=0.004)$ for the Clarity construct and Interest $(F(3,121)=2.80, p=0.043)$. With respect to the practice of showing and explaining content of the topic using the technology (Presentation), the learners did not identify significant differences across the lessons.

Table 3: Student-teachers' score on 3 sub-scales of the lessons ( $M$ and SD)

\begin{tabular}{|l|c|c|c|c|c|c|c|c|c|c|}
\multirow{2}{*}{ Sub-scale } & \multicolumn{2}{|c|}{ Isaac $(\mathrm{N}=30)$} & \multicolumn{2}{c|}{ Nat $(\mathrm{N}=30)$} & \multicolumn{2}{c|}{ Kobby $(\mathrm{N}=31)$} & \multicolumn{2}{c|}{ Serena $(\mathrm{N}=34)$} & \multicolumn{2}{c|}{ ANOVA test } \\
\cline { 2 - 13 } & $\mathrm{M}$ & $\mathrm{SD}$ & $\mathrm{M}$ & $\mathrm{SD}$ & $\mathrm{M}$ & $\mathrm{SD}$ & $\mathrm{M}$ & $\mathrm{SD}$ & $\mathrm{F}$ & $p$ \\
\hline Clarity & 4.39 & 0.40 & 4.29 & 0.42 & 4.58 & 0.22 & 4.53 & 0.26 & 4.77 & $0.004^{*}$ \\
\hline Interest & 4.41 & 0.39 & 4.31 & 0.40 & 4.57 & 0.32 & 4.45 & 0.35 & 2.80 & $0.043^{*}$ \\
\hline Presentation & 4.36 & 0.38 & 4.27 & 0.43 & 4.44 & 0.37 & 4.35 & 0.28 & 1.07 & 0.363 \\
\hline
\end{tabular}

${ }^{*}$ Significant at 0.05 level

The level of difficulty of the various topics taught by the teachers might have contributed to the differences between lessons in the clarity and interest constructs. Student-teachers' guided group discussion confirmed their experiences with SSL. The student-teachers further pointed out that the lessons were very interesting and practical and presentations were attention grabbing promoting class participation. They maintained the lessons were learner-centred promoting higher-order thinking skills and applicable to real life situations. Most of them indicated that they had understood better certain mathematical concepts which they should have learned in senior high schools. The following were some of their responses:

The lesson was a great scaffolding exercise. It gradually unfolded the content of quadratic in the vertex form. In fact I never knew there was an expression for determining the y-coordinate of a parabola in the vertex form; but today I have learnt something new (S11);

I was thinking of how certain concepts could have been developed for students to understand the way we did without the graphs, but the spreadsheet activities helped us to explore the effect of the parameters on the graphs (S23);

I had the opportunity to teach linear equations during my off-campus teaching practice at the SHS; reflecting on what I did and what I just witnessed there is a very big difference. This lesson really brought out the effect of changes on the parameters clearly whereas it was very difficult to get this concept across to the students during my lesson (S25).

In spite of their enthusiasm for SSLs, student teachers pointed out some challenges in teaching a SSL. They speculated that it requires good skills and expertise to design and prepare to teach a SSL. They also expressed concerns about access problems with technological facilities in secondary schools where they were being trained to teach.

\section{Experimental teachers' reflection on their learning}

\section{Looking back at lesson implementation}

The experimental teachers had the opportunity to clarify their opinions about the SSL in a reflective interview after teaching their lessons. They reported several challenges with the process of design SSL itself. Isaac indicated having taught a similar lesson in quadratics once in a senior high school during his off-campus teaching practice. Responding to how different the preparation of the lesson was, compared to what he had taught before, he explained: 
Here it was more difficult and time consuming to prepare (than the one I taught before). Whereas in the former I only prepared a lesson plan and few questions, now we had to prepare a student worksheet in addition to the lesson plan, set up the spreadsheet environment, prepare slides and eventually teach the whole lesson to ourselves before the actual teaching was done.

His team mate added:

It was difficult to think of authentic student activities that tied with the learning objectives in the preparation of the worksheet (Nat).

Kobby vehemently stated that his team also had some problems when designing the lesson. He indicated:

The challenge was to identify and integrate appropriate spreadsheet resources having in mind our learning objectives.

The experimental teachers indicated having problems in designing suitable interactive activities with spreadsheet to guide students towards developing higher concepts. However, they believed the lessons were more student-centred and the development of the mathematics concepts more deductive. When asked what encouraged them to select the topics they taught in their lessons, the teachers explained that it was easier for them to develop lessons in which concept formation could be facilitated by using spreadsheets. Reflecting on their experiences and how comfortable they were teaching the SSL, the teachers said they built their confidence over time and it was easier for them to explain certain concepts with the approach. Isaac indicated:

Some concepts I thought would be difficult to develop was made much easier for me to explain than I would have done before...

The experimental teachers believed that the SSL approach caught the attention of the students and engaged them throughout the lesson, giving them a different role from what they experienced in their normal lessons. They felt that their lessons incorporated more student activities, making it more student-led rather than teacher-led. The four teachers contended that their students enjoyed the lessons and their conceptual understanding of the various topics that were taught had improved tremendously, in spite of the fact that they were teachers supposed to be teaching topics they had learnt several years ago.

Experimental teachers' development of TPCK

Table 4 gives a summary of the results of the pre-post survey delineated by the teachers' expressed self-efficacy of the TPCK components.

Overall the results indicated that there were appreciable increments between the respondents' pre- and post-test means for all four TPCK sub-scales. The largest area of change between the teachers' pre- and post-test mean differences was for the subscale TCK (2.18), followed by TPCK (1.96). Changes in TK and TPK were from approaching agree to agree (in both cases) for the pre to post mean scores. The teachers' prior experiences with spreadsheets knowledge (especially Kobby and Isaac) as indicated in interview responses confirmed this. Experimental teachers reported that the arrangement gave them the experience in learning their subject matter better and thus expanding their knowledge of representing mathematical concepts with spreadsheets (TCK). 
Table 4: Results for pre- and post-test mean score responses for TPCK subscales

\begin{tabular}{|l|l|c|c|c|c|c|}
\hline \multirow{5}{*}{ TK } & & Isaac & Nat & Kobby & Serena & Overall mean \\
\cline { 2 - 7 } & Pre & 4.38 & 3.65 & 4.25 & 3.63 & 3.98 \\
\cline { 2 - 7 } & Post & 4.64 & 4.33 & 4.74 & 4.42 & 4.53 \\
\cline { 2 - 7 } & Change in TK & 0.26 & 0.68 & 0.49 & 0.79 & 0.55 \\
\hline \multirow{5}{*}{ TCK } & Pre & 4.01 & 3.22 & 3.89 & 3.45 & 3.64 \\
\cline { 2 - 7 } & Post & 4.51 & 4.20 & 4.64 & 4.38 & 4.43 \\
\cline { 2 - 7 } & Change in TPK & 0.50 & 0.98 & 0.75 & 0.93 & 0.79 \\
\cline { 2 - 7 } & Pre & 2.55 & 2.13 & 2.35 & 2.04 & 2.27 \\
\cline { 2 - 7 } & Post & 4.76 & 4.18 & 4.48 & 4.39 & 4.45 \\
\hline \multirow{3}{*}{ Change in TCK } & 2.21 & 2.05 & 2.23 & 2.35 & 2.18 \\
\cline { 2 - 7 } & Pre & 2.33 & 1.98 & 2.22 & 1.89 & 2.11 \\
\cline { 2 - 7 } & Post & 4.36 & 3.63 & 4.21 & 4.09 & 4.07 \\
\hline
\end{tabular}

They mentioned having expanded their knowledge on instructional strategies to teach the subject matter with spreadsheet (TPCK). Experimental teachers' improved and developed TPCK also reflected in their lesson enactment. For instance Kobby begun his lesson with the graph of the standard linear function: $y=a x+k$ on the spreadsheet and guided his students to observe and record (on their worksheet) how the graph changes when the gradient $(a)$ was altered (TPCK) (Figure 3).

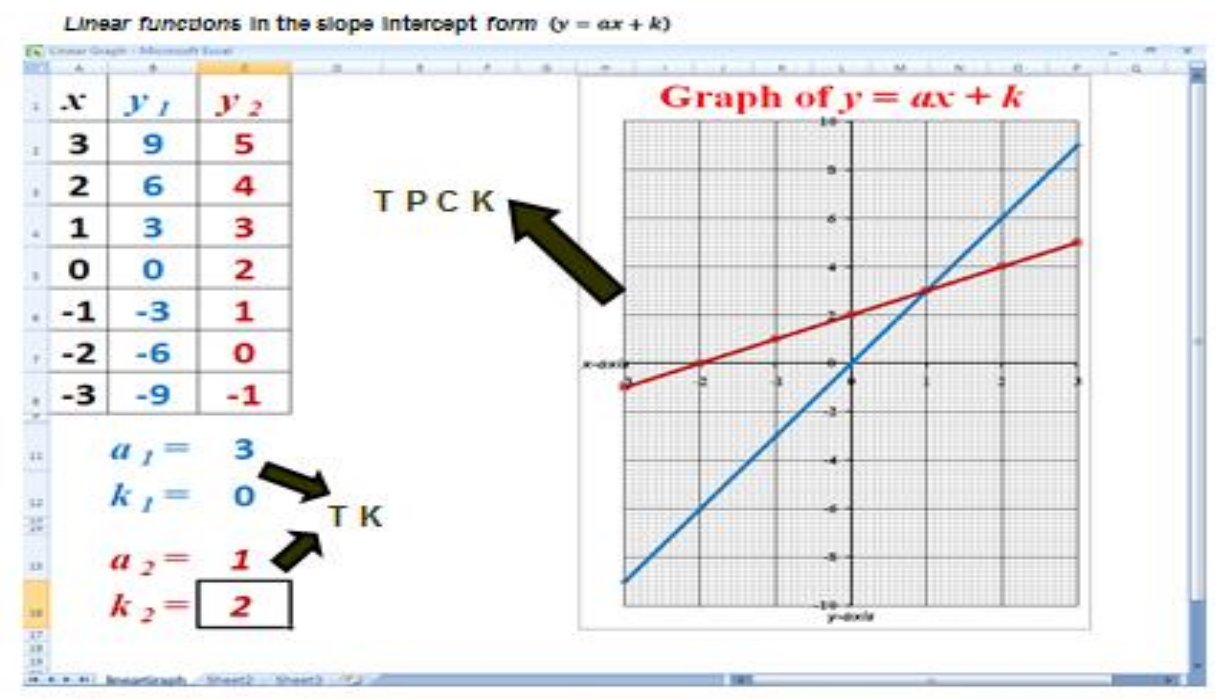

Figure 3: Desktop snapshot of lesson on linear functions: $y=a x+k$

In Serena's lesson, she used spreadsheet to prepare the graph of a standard quadratic function: $y=a x^{2}$ (storing parameters in cells) (TCK), before beginning her lesson on an overhead projector. By using a plot of the graph $y=a x^{2}+b x+c$, Isaac set the value of $a$ to be a positive number in a cell and kept decreasing it through negative numbers as students recorded changes in the graph on their worksheet (TPK).

Zooming out on the coordinates of points $(T K)$ was an improved way to allow students to read and record their own values. Using the "Increase decimal" button on the spreadsheet $(T K)$ helped to show more precise values to verify algebraic solution sets 
in the lesson on simultaneous linear equations by Nat. Experimental teachers considered the intervention useful as it had increased their confidence and competence in teaching mathematics with technology.

The contribution of teacher design teams for experimental teacher learning

The experimental teachers indicated that they enjoyed working in DTs and participated actively in their teams. Specifically the teachers liked the collaboration in team discussions on how to improve lessons, co-plan their lessons, and share ideas. They felt that the support offered in DTs increased their confidence in designing mathematics lessons. More importantly, it helped them improve their teaching performance through sharing experiences and expertise with their immediate colleagues. In addition, they were able to identify their individual strengths and weaknesses. However, though appreciating the importance of design teams and the role these played in enhancing their TPCK, the experimental teachers admitted encountering some challenges when working in teams. The major ones were the time factor and punctuality at design meetings. Different views among members within teams posed challenges during lesson designs and discussions. Nevertheless, they believed that through discussions and negotiations they always came to a compromise. Thus, experimental teachers concluded that by working in design teams, they learnt how to cope with a colleague's ideas on different issues and how to compromise and develop common understanding.

The contribution of exemplary curriculum materials for experimental teacher learning All four teachers considered the exemplary teaching materials as very useful for various reasons: enhancing their skills for teaching SSL (Nat and Kobby), providing a better understanding of the SSLs (All), suggesting suitable classroom activities (Isaac and Kobby), facilitating step by step suggestions on how to proceed with their own designs (Kobby, Serena and Nat) and providing new knowledge on the topics (All). They emphasised the effectiveness of the exemplary materials in designing their own lesson materials. Experimental teachers mentioned using the materials they had modelled themselves (following the exemplary ones) in their future lessons. The various reasons for using such materials were: promoting student-centred learning, arousing interest of students, enhancing understanding of the topic and promoting full participation in the teaching and learning process.

\section{Discussion}

The study aimed to explore the impact of collaborative design teams on pre-service (experimental) teachers' TPCK development and their teaching with technology. Preservice mathematics teachers worked in design teams to plan and organise for teaching mathematics with spreadsheets (supported by exemplary materials) within a mathematics classroom context. The analysis showed that pre-service experimental teachers used spreadsheets extensively to help their students explore mathematics concepts and perform authentic tasks. Spreadsheets were used for verifying results and considering general rules, for making links between spreadsheet formulas, algebraic functions and graphs, for analysing and exploring number patterns and graphs, and for allowing many numerical calculations simultaneously. Consequently, the use of spreadsheets as an instructional tool in their lessons influenced how preservice teachers' pedagogies changed, challenging the way teachers synchronised with student learning. 
This underpins findings by Tee and Lee (2011) that use of technology in the classroom changes the way teachers view teaching and learning. The pre-service teachers were able to use a spreadsheet environment to engage their students in different learning related activities such as viewing presentations, collecting data (on the coordinates of an object) and making predictions of the image location of object or figures in certain mathematical topics. These considerations indicate that pre-service teachers' understanding of technology shifted from viewing technology as a tool for reinforcement, into viewing technology as a tool for developing student understanding of mathematical concepts, in the manner described by Özgün-Koca, Meagher and Edwards (2010). As a result, appreciable levels of growth in components of TPCK (TK, TPK, TCK and TPCK, with pronounced changes in TCK and TPCK) were reported in their self-reports and lesson enactment. What was common to all was that they moved from thinking discretely about technology, pedagogy, and content, to thinking and speaking about them as almost inseparable constructs. Student-teachers' experiences confirmed that the lessons were great scaffolding exercises and more learner-centred, and gave them deeper insights into certain concepts they should have learnt earlier when they were students in secondary schools.

While the study showed that pre-service teachers had acquired technology integration skills during collaborative designs, and had adopted some elements of a learnercentredness approach in their teaching, it was not without difficulties. The pre-service teachers indicated that generating authentic activities and ill-structured problems for their chosen topics was one of the challenges. They also experienced difficulties in finding and integrating appropriate spreadsheet applications for the learning activities. It appears that maximising the potential of the spreadsheet-specific learning tool (as the only technology for designing lessons) leads to difficulties in designing mathematics lesson activities for the pre-service teachers (cf. Holmes, 2009). Holmes' study to introduce interactive whiteboards to pre-service mathematics teachers unveiled the potential problems associated with the overuse of specific learning tools and emphasises the need for pre-service teachers to carefully consider when such tools are appropriate and when other methods might be superior.

Challenges with time management of lesson implementations were evident in the study. As a result lesson conclusions were in a rush and teacher driven. Possibly, lessons were overloaded with activities in some cases and estimating appropriate times with this new experience was a possible challenge for the others. Limited repertoires for teaching mathematics with technology in a student centred approach was another possible reason for pre-service teachers' difficulties in collaborative design and SSL enactment.The context-sensitive factor in which pre-service teachers have been deep-rooted in teacher-centred learning approaches may have influenced their thinking and practices. Furthermore, student-teachers speculated that it requires a lot of effort and expertise to prepare and teach a SSL. These findings illuminate that the teachers needed more time to practise this new approach to mathematics teaching, to develop their TPCK in a more desirable way. This is similar to findings by Fishman and Davis (2006). As expressed by So and Kim (2009):

\footnotetext{
... building a knowledge base of TPCK should be viewed as a long term trajectory that goes beyond pre-service teacher education in formal settings (Fishman \& Davis, 2006). As teachers gain more experience, they can continue to expand their knowledge base and to strengthen the connection between content, pedagogy and technology (So \& Kim, 2009).
} 
In spite of the drawbacks, the overall findings from this study suggest that the development contributed to growth in TPCK and the subsequent implementation of technology-supported mathematics lessons of the pre-service teachers.

A number of factors accounted for the positive impact of DTs. Clearly, collaborative design, which was a new approach at the teacher preparation program at UCC, was a useful approach for pre-service teachers' development of TPCK. Participation in design teams for SSL improved interaction and interdependence among pre-service teachers; enabling them discover how to share knowledge and ideas as well as improve communication and brainstorming on relevant information relating to their designs. As a result, pre-service teachers in design teams increased their knowledge and skills to design and use spreadsheet-supported mathematics lessons. They indicated that their knowledge in their subject matter was enhanced and they were able to make intimate connections among their specific content, pedagogy and technology in a collaborative way (cf. So \& Kim, 2009). The approach changed their teaching practices and beliefs with regards to design and use of ICT-enhanced lessons to support mathematics teaching.

Along with working in DTs, the exemplary materials supported the pre-service teachers by: promoting a better understanding of what integrating technology in lessons is about, promoting pedagogical design capacity, providing concrete 'how to do' suggestions and facilitating a better implementation of the innovation. Lessons that were modelled to them, and their own micro-teaching with the materials, provided a theoretical as well as practical insight into SSL, hands-on experiences, and prompting for their decisions on how to proceed with their own designs (cf. Voogt, 2010). Consequently, the development and use of exemplary materials to support teachers during collaborative design is a promising strategy for DTs in the Ghanaian context.

Although findings from this study do not allow for broad generalisations due to the limited scope and specific context, we believe that they provide information about conditions and opportunities for developing the experiences of future teachers' in the integration of technology, pedagogy and content, in teacher education programs in Ghana. As Voogt (2010) explains, gaining more in-depth knowledge in specific contexts can be considered complementary to findings of large scale studies such as those conducted by Penuel, Fishman, Yamaguchi and Gallagher (2007), and may result in more specific design guidelines for professionals, who are in charge of teacher professional development aiming at technology integration.

In the light of this, the following design guidelines are proposed from the study for use in developing TPCK-competent pre-service mathematics teachers in our context and other regions with similar context (eg. Sub-Saharan Africa).

1. Collaborative design teams (in which pre-service teachers worked with peers) are an important strategy for stimulating and supporting teacher learning. This approach to technology integration will help move pre-service teachers from being passive learners and consumers of technological resources, to being more active learners and producer/designers of technology resources, thereby increasing user involvement and local ownership.

2. Exemplary curriculum materials are an important means as they can inspire teachers to learn and provide a better understanding of an innovation. Demonstrations with exemplary materials could be a way to model technology use, 
but caution should be taken to ensure that exemplary materials provide meaningful and effective examples.

3. For more effective collaboration with the use of the exemplary materials and working in DTs, an orientation program is important. The orientation program could be a workshop, a course, or any professional development arrangement in which conceptual and theoretical information will be linked to the application of knowledge and skills. The orientation is intended to prepare pre-service teachers by giving them the theoretical foundation/ concepts (furnishing teachers with the concept of TPCK, a learner-centred approach to teaching and technology-based possibilities of teaching mathematics), as well as practical skills (basic technology acquisition skills, demonstrations of technology-based lesson examples, team coplan and discussion of lessons and micro/peer teaching) that they need to work successfully in teams.

4. Adaptation of technology that is readily available and user friendly with potential for supporting students' higher-order thinking in mathematics is a key to a successful intervention in integrating technology. This will ensure that pre-service teachers will be designers of technological resources, by learning how to use existing hardware and software in creative and situation specific ways to accomplish their teaching goals. With this, they can integrate available technology in their daily lesson plans and into traditional classroom practice.

5. A complete arrangement to develop pre-service mathematics teachers TPCK should encompass scaffolds and authentic technology experiences, such as teaching tryouts, are an integrated part of the arrangement. Teaching try-outs have the tendency to increase pre-service teachers' enthusiasm to use technology in teaching.

\section{Conclusion}

This study supported the contention that TPCK is a useful analytic lens for studying teachers' integration of technology, content, and pedagogical knowledge, as it develops over time in "learning technology by design" settings. Although the study showed the potential of TPCK to be a new frame for developing experiences for future teachers, it cannot be said that the professional development arrangement fully developed the teachers' TPCK. Further opportunities to experience learning about the affordances of technology applications are necessary for teachers to explore more topics and concepts in their mathematics curriculum to develop their TPCK much better. Another challenge is for teachers to extend the initial knowledge, beliefs and dispositions for teaching with technology as they contend with the real school barriers of time, access and infrastructure. This will be the focus of our next study; to extend this study on pre-service teachers into the real classroom situation.

\section{References}

Angeli, C. \& Valanides N. (2005). Preservice elementary teachers as information and communication technology designers: An instructional systems design model based on an expanded view of pedagogical content knowledge. Journal of Computer Assisted Learning, 21(4), 292-302. http: / / dx.doi.org/10.1111/j.1365-2729.2005.00135.x

Agyei, D. D. \& Voogt, J. (2011a). ICT use in the teaching of mathematics: Implications for professional development of pre-service teachers in Ghana. Education and Information Technologies, 16(4), 423-439. http:/ / dx.doi.org/10.1007/s10639-010-9141-9 
Agyei, D. D. \& Voogt, J. (2011b). Exploring the potential of the will, skill, tool model in Ghana: Predicting prospective and practicing teachers' use of technology. Computers $\mathcal{E}$ Education, 56(1), 91-100. http:/ / dx.doi.org/10.1016/j.compedu.2010.08.017

Anamuah-Mensah National Education Review Committee Report (2002). Report of the President's Committee on Review of Education Reforms in Ghana. Ministry of Education, Accra, Ghana.

Davis, E. A. \& Krajcik, J. (2005). Designing educative curriculum materials to promote teacher learning. Educational Researcher, 34(3), 3-14. http: / / dx.doi.org/10.3102/0013189X034003003

Fishman, B. \& Davis, E. (2006). Teacher learning research and the learning sciences. In R. K. Sawyer (Ed.), Cambridge handbook of the learning sciences (pp. 535-550). Cambridge: Cambridge University Press.

Ghana ICT4AD Policy (2003). A policy statement for the realization of the vision to transform Ghana into an information-rich knowledge-based society and economy through the development, deployment and exploration of ICT's within the economy and society. Ministry of Education, Accra, Ghana.

Holmes, K. (2009). Planning to teach with digital tools: Introducing the interactive whiteboard to pre-service secondary mathematics teachers. Australasian Journal of Educational Technology, 25(3), 351-365. http:/ / www.ascilite.org.au/ajet/ajet25/holmes.html

Koehler, M. J. \& Mishra, P. (2008). Introducing technological pedagogical content knowledge. In AACTE Committee on Innovation and Technology (Eds.), Handbook of technological pedagogical content knowledge for teaching and teacher educators, 3-29. New York: Routledge.

Koehler, M. \& Mishra, P. (2005). What happens when teachers design educational technology? The development of technological pedagogical content knowledge. Journal of Educational Computing Research, 32(2), 131-152. [verified 12 Apr 2012] http:/ / punya.educ.msu.edu/publications/journal_articles /Koehler_Mishra_JECR05.pdf

Koehler, M. J., Mishra, P. \& Yahya, K. (2007). Tracing the development of teacher knowledge in a design seminar: Integrating content, pedagogy and technology. Computers E Education, 49(3), 740-762. http:/ / dx.doi.org/10.1016/j.compedu.2005.11.012

Margerum-Leys, J. \& Marx, R. W. (2004). The nature and sharing of teacher knowledge of technology in a student teacher/mentor teacher pair. Journal of Teacher Education, 55(5), 421437. http: / / dx.doi.org/10.1177/0022487104269858

Miles, M. B. \& Huberman, A. M. (1994). Qualitative data analysis: An expanded sourcebook. 2nd Edition. London, SAGE Publications. http:/ / www.sagepub.com/books/Book4314

Ministry of Education, Science and Sports (2007). Teaching syllabus for mathematics. Ministry of Education, Accra, Ghana.

Mishra, P., Koehler, M. J. \& Zhao, Y. (2007). Faculty development by design: Integrating technology in higher education. Charlotte, NC: Information Age Publishing.

Niess, M. L., Sadri, P. \& Lee, K. (2007). Dynamic spreadsheets as learning technology tools: Developing teachers' technology pedagogical content knowledge (TPCK). Paper presented at the American Educational Research Association Annual Conference, April, Chicago, IL.

Niess, M. L. (2005). Preparing teachers to teach science and mathematics with technology: Developing a technology pedagogical content knowledge. Teaching and Teacher Education, 21(5), 509-523.

Ottevanger, W., van den Akker, J. J. H. \& de Feiter, L. (2007). Developing science, mathematics and ICT education in Sub-Saharan Africa (SMICT): Patterns and promising practices. World Bank Working Paper (101), pp. 1-84.

Ottevanger, W. (2001). Teacher support materials as a catalyst for science curriculum implementation in Namibia. Unpublished doctoral dissertation, University of Twente, Enschede. 
Özgün-Koca, S. A., Meagher, M. \& Edwards, M. T. (2010). Preservice teachers' emerging TPACK in a technology-rich methods class. The Mathematics Educator, 19(2), 10-20. [verified 6 May 2012] http:/ / math.coe.uga.edu/TME/Issues/v19n2/v19n2_Ozgun-Koca,\%20Meagher,\%20\&\%20Edwards.pdf

Penuel, W. R, Fishman, B. J., Yamaguchi, R. \& Gallagher, L. P. (2007). What makes professional development effective? Strategies that foster curriculum implementation. American Educational Research Journal, 44(4), 921-958. http:/ / dx.doi.org/10.3102/0002831207308221

Polly, D., Mims, C., Shepherd, C. E. \& Inan F. (2010). Evidence of impact: Transforming teacher education with preparing tomorrow's teachers to teach with technology (PT3) grants. Teaching and Teacher Education, 26(4), 863-870. http:/ / dx.doi.org/10.1016/j.tate.2009.10.024

Remillard, J. T. (2005). Key concepts in research on teachers' use of mathematics curricula. Review of Educational Research, 75(2), 211-246. http: / / dx.doi.org/10.3102/00346543075002211

Schmidt, D. A., Baran Sahin, E., Thompson, A. D., Mishra, P., Koehler, M. J. \& Shin, T. S. (2009). Technological pedagogical content knowledge (TPCK): The development and validation of an assessment instrument for preservice teachers. Journal of Research on Technology in Education, 42(2), 123-149. http:/ / www.iste.org/learn/ publications/journals /jrteissues / Technological_Pedagogical_Content_Knowledge_TPACK_The_Development_and_V alidation_of_an_Assessment_Instrument_for_Preservice_Teachers.aspx

Schmidt, D., Baran Sahin, E., Thompson, A. \& Seymour, J. (2008). Developing effective technological pedagogical and content knowledge (TPCK) in preK-6 teachers. In K. McFerrin et al. (Eds.), Proceedings of Society for Information Technology $\mathcal{E}$ Teacher Education International Conference 2008 (pp. 5313-5317). Chesapeake, VA: AACE. http:/ / www.editlib.org/p/ 28124

Shulman, L. S. (1986). Those who understand: Knowledge growth in teaching. Educational Researcher, 15(2), 4-14. http:/ / dx.doi.org/10.3102/0013189X015002004

So, H.-J. \& Kim, B. (2009). Learning about problem based learning: Student teachers integrating technology, pedagogy and content knowledge. Australasian Journal of Educational Technology, 25(1), 101-116. http: / / www.ascilite.org.au/ajet/ajet25/ so.html

Tee, M. Y. \& Lee, S. S. (2011). From socialisation to internalisation: Cultivating technological pedagogical content knowledge through problem-based learning. Australasian Journal of Educational Technology, 27(1), 89-104. http: / / www.ascilite.org.au/ ajet/ ajet27/ tee.html

Tilya, F. (2008). IT and educational policy in the Sub-Saharan African region. In J. Voogt \& G. Knezek (Eds.), International handbook of information technology in primary and secondary education (pp.1145-1159). New York: Springer.

Van den Akker, J. J. (1988). The teacher as learner in curriculum implementation. Journal of Curriculum Studies, 20(1), 47-55. http: / / dx.doi.org/ 10.1080/0022027880200104

Voogt, J. (2010). A blended in-service arrangement for supporting science teachers in technology integration. Journal of Technology and Teacher Education, 18(1), 83-109. http:/ / editlib.org/p/28359

Yin, R. K. (1993). Applications of case study research. Thousand Oaks, CA: Sage.

Authors: Douglas D. Agyei (corresponding author), Department of Mathematics and Statistics, University of Cape Coast, Cape Coast, Ghana. Email: d.d.agyei@utwente.nl

Associate Professor Joke Voogt

Department of Curriculum Design and Educational Innovation

Faculty of Behavioural Sciences, University of Twente

P.O. Box 217, 7500AE Enschede, The Netherlands. Email: j.m.voogt@utwente.nl

Please cite as: Agyei, D. D. \& Voogt, J. (2012). Developing technological pedagogical content knowledge in pre-service mathematics teachers through collaborative design. Australasian Journal of Educational Technology, 28(4), 547-564.

http: / / www.ascilite.org.au/ajet/ajet28/agyei.html 